\title{
Reconciling his history: How revisiting the memory of Cook's visit facilitated a process of reconciliation within the Cooktown community from 1998 to 2019
}

\author{
Charlotte Ward
}

\begin{abstract}
Reconciliation has been a political concern since the early 1990s. However, on a national level, reconciliation between non-Indigenous and Indigenous Australians is yet to be realised. In more recent years, the process has moved from a national symbolic movement to a more localised level. This article analyses the processes and performances of reconciliation that have taken place in Cooktown since the early 1990s and have attracted national attention. Specifically, their annual re-enactment of Captain Cook's visit in 1770 has transformed from a narrative of colonisation to one of reconciliation. This article argues that it is the very local processes of engaging with the history that has made history a useful tool to help facilitate forms of reconciliation between Indigenous and non-Indigenous residents in Cooktown. This is most evident in the way the script of Cooktown's annual re-enactment has been rewritten and the performance expanded and changed as a result. In tracing this and other local history projects, the article reveals the ways in which a linear, yet inclusive, narrative has been created, as well as how new spaces have been prised open for telling new histories. The article concludes by reasserting the strengths of a grassroots approach to reconciling history.
\end{abstract}


On 11 June 1770, close to midnight, Captain Cook's infamous Endeavour struck what is now known as the Great Barrier Reef, roughly 12 miles from the coastline. Cook and the crew, in a desperate mission to save the ship and their lives, threw heavy objects overboard and tried to plug the hole in the Endeavour. Hours later, they managed to 'fother' it and navigate a safe passage through the coral reef to the mainland. There they found themselves on the shores of Waalumbaal Birri, which they later named Endeavour River. Cook and his crew stayed there for 48 days, repairing the Endeavour, assessing flora and fauna, stocking up on food and documenting their experiences. It was here on the shores of the Endeavour River in 1770 that the crew recorded the Aboriginal language Guugu Yimithirr and adopted the word 'gangurru', from which evolved the English word 'kangaroo'. During their stay, Cook and his crew had multiple exchanges with the Guugu Yimithirr people some of which have become more historically prominent than others. This is a brief overview of the history that is remembered in the name, Cooktown, given to the settlement that emerged 100 years later. ${ }^{1}$

I came across Cooktown in the final semester of my undergraduate degree, during my internship at the National Museum of Australia (NMA). I was working on the 2020 exhibition of Captain Cook's 1770 voyage along the east coast of Australia. The NMA was one of the national institutions that received funding from the federal government to create an exhibition that represented 'the perspectives of both non-Indigenous and Indigenous Australians about Cook's voyage and its continuing and contested legacies today ... by counterpointing the "view from the ship" with "the view from the shore"'. The Endeavour 250 curatorial team was representative of these perspectives - made up of Indigenous and non-Indigenous curators. My role was to undertake research on the Indigenous languages at the locations Cook observed on his voyage. Given that the Endeavour expedition had collected some Guugu Yimithirr vocabulary, it was one of the languages I began to research, which brought me to Cooktown.

Through my work at the NMA, I became aware that there was a long commemorative history of celebrating Cook's visit in and around Cooktown. The story I first heard was one of apparent reconciliation between Cook and the Guugu Yimithirr people. I was curious how Cook's history could lead to an understanding of reconciliation,

\footnotetext{
1 See, Molony, 'The Guugu Yimithirr', 105-17; McKenna, 'On Grassy Hill: Gangaar (Cooktown), North Queensland', 189-95; McCalman, The Reef, 27-49.

2 'Australian Government Commemorates Cook 250', James Cook 250, accessed 13 May 2021, jamescook250. org/australian-government-commemorates-cook-250/.
} 
particularly when in the popular imagination he is seen as a destructive and divisive figure, associated more with conflict than with reconciliation. ${ }^{3}$ This paradox led me to this research.

In Cooktown, Cook's visit had been historically performed and remembered as a moment of possession; the place where he came ashore and allegedly claimed Australia for His Majesty King George III. But, in the late 1990s, some residents of Cooktown started to look more critically into this local history by attempting to understand the encounters that took place between the Endeavour's crew and the Guugu Yimithirr people in 1770. This critical approach, reflective of developments in historical treatments of early contact history more broadly, ${ }^{4}$ resulted in a collaboration between Indigenous and non-Indigenous community members through which the annual Cook re-enactment was rescripted; the local James Cook Museum allocated exhibition space to tell the Indigenous perspective of the encounters; and new monuments were added alongside the numerous Captain Cook tributes in the local landscape. ${ }^{5}$ Alongside the re-envisioning of Cook's visit, other histories began to be publicly shared in Cooktown, including those which shed light on Guugu Yimithirr histories, pre- and post-Cook. Community members also began to use the encounters in 1770 as a platform to publicly discuss more difficult histories of Indigenous and non-Indigenous relations, which facilitated new understandings of these relations in the present. ${ }^{6}$

This article analyses the sites and projects of reconciliation in Cooktown from the 1990s to the present. It examines the ways in which the popular historical narratives and understandings have been redefined through community processes of 'sharing histories'. Popular sites and practices of historical remembrance such as performances, the museum and both existing and new monuments are examined and described to understand the politics of reconciliation in Cooktown. As the meanings of these public sites of remembrance are activated through engagement with them,

3 See, Rose, Hidden Histories, 15-25; Nugent, Captain Cook Was Here, 105-36; Healy, 'Captain Cook and Death: Black Histories of Cook', Chapter 2 in From the Ruins of Colonialism, 42-73; Gordon Bennett, Possession Island, 1991, oil and synthetic polymer paint on canvas, Museum of Sydney, Sydney Living Museums; Daniel Boyd, We Call Them Pirates Out Here, 2005, oil on canvas, Museum of Contemporary Art, Sydney; Daniel Boyd, Captain No Beard, 2005, oil on canvas, National Gallery of Australia, Canberra; Dianne Jones, LHOOQ ERE!, 2001, photographs, Inkjet on canvas, National Gallery of Australia, Canberra; Chittick and Fox, Travelling with Percy; Healy, "'We Know Your Mob Now"', 27-33.

4 Clendinnen, Dancing with Strangers; Dening, Beach Crossings; Dening, Performances; Nugent, Captain Cook Was Here; Thomas, Cook; Thomas, Entangled Objects.

5 McKenna, 'Gangaar (Cooktown), North Queensland', 199-212; 'Loretta Sullivan and Alberta Hornsby April Luncheon', YouTube video, University of Melbourne, 9 July 2015, 00:01:49-1:19:07, www.youtube.com/watch? $\mathrm{v}=$ p0um3oj4FWE.

6 Alberta Hornsby, 'Dispelling the Myths, Oral history through the Guugu Yimithir people of contact with Cook and his crew', Cook's Treasures Seminar, 24 February 2012, National Library of Australia, accessed 18 September 2019, www.nla.gov.au/events/cooks-treasures/papers/Alberta-Hornsby-national-library.pdf; 'Loretta Sullivan and Alberta Hornsby April Luncheon', 1:49-1:19:07.

7 Goodall, 'Too Early yet or Not Soon Enough?'; Attwood, 'Unsettling Pasts'; Edmonds, “"Walking Together” for Reconciliation'. 
I draw on my experience of visiting Cooktown in June 2019 to participate in the annual 'Discovery Festival'. This is supplemented by publicly available interviews and lectures given by key community members who have been instrumental in this process of 'sharing histories'. Recently, a number of historians and cultural theorists have discussed the nature and politics of remembering Cook in Cooktown, and the article draws on their insights. ${ }^{8}$ In particular, historian Mark McKenna has discussed the local landscape of history and memory to make the broader argument that 'Cooktown's founding moment is one guiding light' for Australia to understand how to reconcile with its complicated history of oppression for a democratic society. ${ }^{9}$

This essay argues that it is not Cooktown's founding moment that is significant for reconciliation, but rather the local processes of engaging with history in the present; significantly, it is the ongoing working relationship between Indigenous and non-Indigenous residents in Cooktown that has facilitated processes of reconciliation. This is most evident in the process by which the script of the re-enactment has been rewritten and the performance expanded and changed as a result. Tracing this and other local history projects, the article reveals the ways in which a linear, yet inclusive, narrative has been created, as well as how new spaces have been prised open for telling new histories. The article concludes by reasserting the strengths of a grassroots approach to reconciling history.

\section{Revising the past}

Prior to 1998, Cook was publicly remembered in Cooktown for his founding achievements. ${ }^{10}$ From 1959 to 2008, the pivotal scene in the annual re-enactment was borrowed from the possession ceremony that took place on Possession Island, where Cook raised the Union Jack, claiming the east coast for His Majesty King George III. ${ }^{11}$ In the Cooktown re-enactment's version of this event, muskets were fired towards the Guugu Yimithirr people as they stood behind the flag, and they consequently disappeared into the bushes. The possession ceremony was then acted out in their absence and muskets were fired into the sky in commemoration. This was the final scene. The re-enactment finished, real time began, and the rest, as they say, 'is history'. ${ }^{12}$

\footnotetext{
8 McKenna, 'Gangaar (Cooktown), North Queensland'; McCalman, The Reef; Molony, 'The Guugu Yimithirr'; Thomas, 'Epilogue' in Discoveries; Bennett, 'Part III: Assembling and Governing Cultures', 201-90.

9 McKenna, 'Gangaar (Cooktown), North Queensland', 210.

10 McKenna, 'Gangaar (Cooktown), North Queensland', 198-99.

11 '1770 - Part 2 - The Re-enactment', YouTube video, 00:05:21-00:05:51, OzPix, 20 August 2008, accessed 27 February 2019, www.youtube.com/watch?v=6076mu47pfk; 'Cook's Journal: Daily Entries, 22 August 1770', South Seas, accessed 24 July 2019, southseas.nla.gov.au/journals/cook/17700822.html.

12 '1770 - Part 2 - The Re-enactment', 6:22.
} 
Cook was the hero and the founder in this re-enactment, and the Guugu Yimithirr people were marginal. They were on the periphery of the stage, and once the flag was raised they became the backdrop to the performance. ${ }^{13}$ Much like similar re-enactments that took place in Kurnell and various other places around Australia, there was no opening scene detailing the lives of Indigenous peoples before Cook arrived and no closing scene pondering their lives after his departure. Their disappearance into the bush marked the re-enactment's finale, and thus the difficult shared history that followed with British colonisation was evaded. ${ }^{14}$

Storytelling is powerful. ${ }^{15}$ The story of Cook taking possession of Australia has been used synonymously with terra nullius; the belief that this land belonged to no one before Cook claimed it. ${ }^{16}$ The use of this story in Cooktown performed a similar purpose; it reasserted white possession of the area. This was not a true representation of what took place on the shore of Waalumbaal Birri in 1770, and the Cooktown community felt that this story needed to be retold.

In the late 1990s, the process of revising the story of Cook's visit began with the collaboration of Eric Deeral and John MacDonald. MacDonald was an actor and local resident of Cooktown, and he contacted Indigenous Elder and former politician Eric Deeral to assist him with the process of rescripting the annual re-enactment. ${ }^{17}$ Deeral had approached this task before. Iain McCalman recalls that to support the Guugu Yimithirr land rights claim in the early 1990s, Deeral:

had assembled a set of portfolios placing local oral traditions and topographical investigations alongside research done on Western lines, thereby creating an empirically based record of the long-term presence of this tribe and its clans area. ${ }^{18}$

Furthermore, Cook's journals had provided written evidence of the Guugu Yimithirr people's connection to the land. McCalman remembers Deeral 'grinning broadly' and saying 'Cook was now helping to repair some of the damage he'd begun'. ${ }^{19}$ On 11 November 1997, the Premier of Queensland signed off on the agreement that recognised traditional and non-traditional owners of Hope Vale. ${ }^{20}$ The clans of Hope Vale had won their native title claim for 110,000 hectares of Cape York

\footnotetext{
13 '1770 - Part 2 - The Re-enactment', 0:00:00-00:08:01.

14 ' 1770 - Part 2 - The Re-enactment', 6:10.

15 Behrendt, 'Speaking Out'.

16 Nugent, Captain Cook Was Here.

17 McKenna, 'Gangaar (Cooktown), North Queensland', 199.

18 McCalman, The Reef, 21-22.

19 McCalman, The Reef, 22.

20 Hope Vale was a Lutheran mission that neighboured Cooktown. During the campaign for native title, the land was occupied by a number of clans. Some clans were traditional owners and some were not, but had historical ties to the land. After some time, these clans came into agreement with boundaries and put forward a proposal for their native title claim as 'the Congress of Clans'. French, 'A Moment of Change'.
} 
from Cooktown to the Jeannie River. ${ }^{21}$ Larissa Behrendt argues that sharing stories is a way of telling truth. Truth that has a far greater reach than arguments for legislative reform and political recognition. ${ }^{22}$ Revising the encounter between the British and the Guugu Yimithirr was more than just rescripting the re-enactment: it was a process of revising popular history that had previously overshadowed, indeed denied, the Guugu Yimithirr people's rights to their Country. Their participation as co-authors of the story, and as prominent participants in the performance, would contribute to replacing denial with recognition. This was an act of truth-telling. ${ }^{23}$

Rescripting the re-enactment required a collaborative approach from non-Indigenous and Indigenous community members. Penny Edmonds, in her analysis of the Myall Creek Massacre memorial, suggests that privileging Indigenous epistemology and taking a grassroots approach to the commemoration was vital to the ceremony at Myall Creek being an active performance of reconciliation. ${ }^{24}$ In their journals, Cook and Banks described events that unfolded at Waalumbaal Birri, ${ }^{25}$ and detailed their encounters with the Guugu Yimithirr people. But their observations were limited by their European perspective and understanding. ${ }^{26}$ The re-enactment had reflected a popular historical narrative of Captain Cook since its establishment in 1959 that rested on an Anglo-Australian perspective. In order to reconcile this popular understanding of the encounters, the research process focused on understanding the actions of the Guugu Yimithirr people through oral histories that existed in the Guugu Yimithirr community. ${ }^{27}$

One exchange in particular, between Cook and an old Guugu Yimithirr man, became the focal point of the re-enactment, and prompted rich cultural exchange within the research process. Towards the end of the Endeavour's stay, two Guugu Yimithirr men came aboard the vessel, in what was supposed to be a civil exchange similar to those that had taken place over the previous days. Cook had gone on an inland expedition to view the land from a nearby hill. But on boarding the ship, the Guugu Yimithirr men saw 12 turtles on the deck that the crew had hunted over the previous days. They tried to grab the turtles, but the crewmembers present would not let them. Things became hostile. The Guugu Yimithirr men left the Endeavour.

\footnotetext{
21 French, 'A Moment of Change'.

22 Behrendt, 'Speaking Out', 11.

23 Edmonds, "Walking Together” for Reconciliation', 90-125.

24 Edmonds, “"Walking Together” for Reconciliation', 115-25.

25 As noted previously, Waalumbaal Birri is the river that Cook named Endeavour River. 'Loretta Sullivan and Alberta Hornsby April Luncheon 2015', 35:50.

26 'Cook's Journal: Daily Entries, 19 July 1770', South Seas, accessed 23 September 2019, southseas.nla.gov.au/ journals/cook/17700719.html; 'Banks’s Journal: Daily Entries, 19 July 1770', South Seas, accessed 7 October 2019, southseas.nla.gov.au/journals/banks/17700719.html.

27 McKenna, 'Gangaar (Cooktown), North Queensland', 199-210; 'Loretta Sullivan and Alberta Hornsby April Luncheon 2015', 38:10-40:15; Hornsby, 'Dispelling the Myths'.
} 
The following day more Guugu Yimithirr men came to the Endeavour and again tried to grab the turtles. A scuffle took place on board and the Guugu Yimithirr men left the Endeavour, emptyhanded. Following their departure, they set the coastline alight, engulfing some of the crew's belongings and a pig. Gunshots were fired at the Guugu Yimithirr people and the Guugu Yimithirr men threw spears at the crew, which the crew grabbed.

After some time had passed, accompanied by a younger man, an old man stepped out of the bush, wiping his armpits and inhaling the sweat from his hands, holding a spear without a point. Cook approached the man and saw this as a sign of peace. He gave the old man the spears back, which Cook believed 'reconciled everything'. ${ }^{28}$ The two parted ways and the Guugu Yimithirr people did not approach the Endeavour again for the remainder of their stay. ${ }^{29}$

This exchange between the old Guugu Yimithirr man and Cook became the central focus in the work to reinterpret and re-remember Cook's visit. By analysing this event from the perspectives of the British crew and the Guugu Yimithirr people, the community members involved in the research developed a new understanding of Cook's encounters and time there. ${ }^{30}$ The performance became both commemorative as well as educative as it began to move away from its monumental origins as a possession narrative and to reveal other truths to community members about the landscape they occupied and the traditional owners whose land had been taken from them. ${ }^{31}$

Through their research, the community members discovered that the site on which Cooktown was built was a place of neutrality - it was used for birthing and as a meeting place at which no blood was to be spilled. They further learnt that the ceremony performed by the old man was ngalangundaama - a ceremony for peace. ${ }^{32}$ Moreover, the disagreement between Cook and the Guugu Yimithirr men shed light on hunting practices that worked with the seasons - helping to explain the local men's anger about the dead turtles they saw on the deck. These practices came into conflict with the crew's aims to stock up on food for their journey home. The research became much more than rescripting the past, it became a pedagogical process of exchange between two cultures.

\footnotetext{
28 'Cook's Journal: Daily Entries, 19 July 1770'; 'Banks's Journal: Daily Entries, 19 July 1770'; McKenna, 'Gangaar (Cooktown), North Queensland', 189-95; McCalman, The Reef, 37-41; Molony, 'The Guugu Yimithirr', 112-15; Ward, 'The Re-Enactment 2019 Part V', 0:00-9:46.

29 Molony, 'The Guugu Yimithirr', 112-15; McKenna, 'Gangaar (Cooktown), North Queensland', 189-95; McCalman, The Reef, 37-41.

30 McKenna, 'Gangaar (Cooktown), North Queensland', 199; 'Loretta Sullivan and Alberta Hornsby April Luncheon 2015', 37:23-1:10:56.

31 Edmonds, "Walking Together” for Reconciliation', 117; Nietzsche, The Use and Abuse of History.

32 Mark McKenna, 'Essay - Unkept Promises', National Library of Australia, accessed 11 February 2019, www. nla.gov.au/digital-classroom/senior/Cook/Indigenous-Response/Mark-McKenna; 'Loretta Sullivan and Alberta Hornsby April Luncheon 2015', 37:23-1:10:09; Hornsby, 'Dispelling the Myths'.
} 
The research helped not only to develop the understanding of the encounter in 1770, but also an understanding of both the Guugu Yimithirr's and the crew's cultural practices more broadly. Eric Deeral's niece, Alberta Hornsby, recalls seeing the re-enactment for the first time in 2008, and being 'disheartened by the lack of Guugu Yimithirr history' that was performed. ${ }^{33}$ As a result, she became involved with the re-enactment, and Deeral encouraged her to read the Endeavour journals. As Hornsby became more involved in the revision of the encounters that took place in 1770, she developed an admiration both for Cook and for her ancestors. She read the journals closely and began to learn more about her own history and her people. ${ }^{34}$ The rescripting of the re-enactment moved beyond the performance, as it sparked a process of 'sharing histories' and cultural understandings that helped reshape local understanding of the Guugu Yimithirr people and settlers. ${ }^{35}$

Cook had been remembered for the purpose of territorial possession since the town's establishment; the research process began to unsettle that story. ${ }^{36}$ The process of rescripting the re-enactment had reduced Cook to a participant in the performance, rather than the lead. As a result, the new story of the Endeavour's stay began to look beyond Cook and appreciate the complex interactions that surrounded him. Hornsby discusses her distaste for Cook when she was a child, and her later appreciation for his navigational skills and his diplomacy as she became part of the research process. ${ }^{37}$ In this way rather than situating Cook as a promise of peace and reconciliation', as McKenna argues, he is reduced from his mythical dichotomy of founder and dispossessor and set aside as merely a participant in history. ${ }^{38}$

The rescripting of the encounter also facilitated institutional change and attracted government funding. In July 2001, Queensland Senator and Federal Regional Services Minister Ian Macdonald announced that the Commonwealth Government would be supporting the renovation and extension of the James Cook Museum by donating $\$ 2.3$ million. At this time, Eric Deeral was commissioned to rewrite the history of the encounter in 1770 for the museum. ${ }^{39}$ Macdonald stated that 'This close liaison has brought to this project a balanced perspective of historical events and objects, giving visitors a unique European and Indigenous perspective to one of the significant events in Australian history..$^{40}$ The renovation was planned to help attract more tourists to the area and to incorporate the Guugu Yimithirr

\footnotetext{
33 National Museum of Australia, 'Sequence_06_Alberta_Hornsby_Overlay', October 2018, 12:50.

34 National Museum of Australia, 'Sequence_06_Alberta_Hornsby_Overlay', October 2018, 20:10; 'Loretta Sullivan and Alberta Hornsby April Luncheon 2015', 37:23-43:04.

35 McKenna, 'Gangaar (Cooktown), North Queensland', 199-211.

36 McKenna, 'Gangaar (Cooktown), North Queensland'.

37 'Loretta Sullivan and Alberta Hornsby April Luncheon 2015', 37:23-40:15.

38 McKenna, 'Gangaar (Cooktown), North Queensland', 209.

39 Ian Macdonald, 'Cooktown Museum Project', Media release, Parliament of Australia, 20 July 2001, accessed 18 September 2019, parlinfo.aph.gov.au/parlInfo/search/display/display.w3p;query=Id:\%22media/pressrel/OFP46 $\% 22 ; \mathrm{src} 1=s \mathrm{~m} 1$.

40 Macdonald, 'Cooktown Museum Project'.
} 
perspective of the past. Rescripting the re-enactment began to have an effect on the institutional representation of history in the town, one that began to portray a shared perspective of the past.

The process of 'sharing histories' within Cooktown has led to the incorporation of other histories into the town's local history. In 1998, the Milbi Wall (story wall) was built in Cooktown. It was positioned on the banks of the Waalumbaal Birri where Cook and his crew came ashore. The wall is divided into three sections: creation stories that confirm the long history of the Guugu Yimithirr people; stories about the effects of white occupation that began with Cook and continued with settlement of Cooktown; and representations of the significance of the 1967 referendum when Aboriginal people were first counted in the reckoning of the nation and responsibility for Aboriginal affairs was assumed by the federal government. ${ }^{41}$ The wall was constructed as a reconciliation project by Gungarde Aboriginal Corporation, which is a local Aboriginal community-focused organisation that provides accommodation, health programs, access to education and work opportunities, 'whilst promoting the preservation of Aboriginal social and cultural integrity' in Cooktown and the surrounding areas. ${ }^{42}$ As cultural theorist Tony Bennett observes, the wall 'asserts a long pre-invasion history, which also relativises the moment of "discovery" as merely one in a succession of contact histories. ${ }^{43}$ Cook's visit is conveyed as an episode, yet an episode that is an exception to the rule of the violent EuropeanAboriginal relations that followed. In this instance, Cook provides an example of respectful relations, even as the wall continues to tell the history of the Guugu Yimithirr people, which also actively undermines Cook's actions of possession as the land was already possessed. ${ }^{44}$

Cook's visit has also been used as a platform beyond Cooktown to discuss and challenge conflicting and 'untruthful' histories. In 2012, for instance, Alberta Hornsby delivered a lecture at the National Library of Australia's 'Cook's Treasures' seminar. ${ }^{45}$ She used Cook's visit to Waalumbaal Birri to discuss common assumptions that she called myths. She discussed terra nullius, and used the evidence of Cook's encounters with Indigenous peoples to show and confirm that terra nullius was and is a myth. Here she further expanded to teach the audience about the culture, language and history of the Guugu Yimithirr people. The second myth she discussed was that the crew from the Endeavour had raped the Guugu Yimithirr women. She suggested there is no evidence for this, but she used this topic as a prompt to talk about the violent treatment and dispossession of Aboriginal people since settlement. The final

\footnotetext{
41 'The 1967 Referendum - Fact Sheet 150', National Archives of Australia, accessed 25 April 2019, www.naa. gov.au/sites/default/files/2020-05/fs-150-the-1967-referendum.pdf.

42 'About Gungarde', accessed 16 October 2019, www.gungarde.org/about.html.

43 Bennett, 'Part III: Assembling and Governing Cultures', 273.

44 Thomas, 'Epilogue'.

45 Hornsby, 'Dispelling the Myths'.
} 
myth that she presented was that the conflict from the Endeavour voyage continued to this day. She used this myth to talk about the diplomacy that Cook and the old Guugu Yimithirr man showed in 1770, and suggested that the current process of reconciliation can learn a lot from the simplicity of this exchange, particularly giving the spears back. This alludes to the topics of native title and Aboriginal sovereignty. Hornsby tactfully used the exchange that took place in 1770 to discuss current political tensions and the lessons that can be learnt from the past. The story of Cook and the old Guugu Yimithirr man has become a platform for discussion on reconciliation processes more broadly. ${ }^{46}$

\section{Ritualising reconciliation}

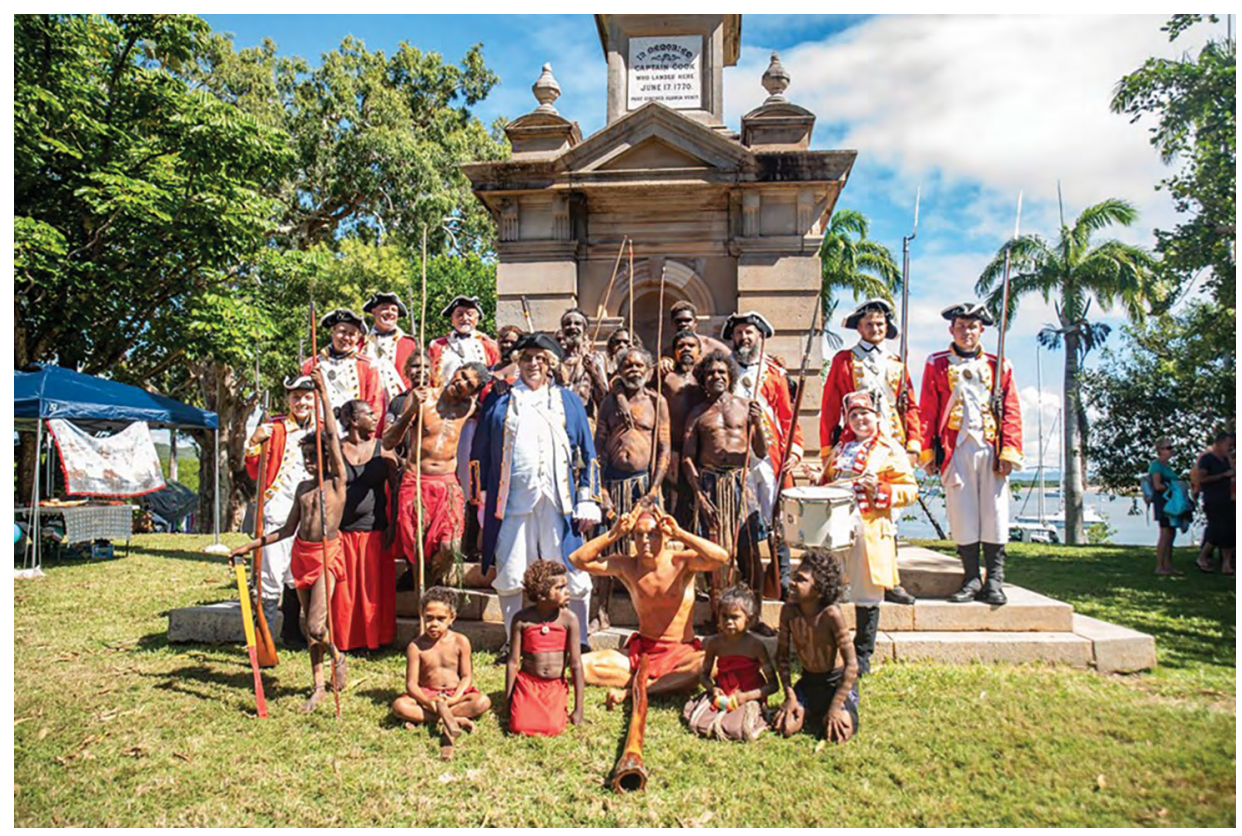

Figure 1: The re-enactment crew at Cook's Monument, 2019.

Source: With permission from the Cook Shire Council.

After more than 10 years of collaborative work, the new script was debuted in 2009 for the 50th anniversary of the Cooktown re-enactment. Hornsby and long-serving member of the Re-enactment Association, and the then president, Loretta Sullivan were largely responsible for presenting the new narrative. 'Two cultures, one people' was the theme of the re-enactment. The Re-enactment Association 'wanted to complete the story based on fact by researching Cook's accounts of events', ${ }^{47}$ but it

46 McKenna, 'Gangaar (Cooktown), North Queensland'.

47 'The Discovery Festival', The Weekend Post, 19 September 2009. 
had become more than this. In the process, the research had become a rich cultural exchange between Indigenous and non-Indigenous understandings of the past. The process of 'sharing histories' had become the product of a new 'shared history' that allowed space for different perspectives and epistemologies. ${ }^{48}$

In 2019, I visited Cooktown to experience the 'Discovery Festival'. The Discovery Festival was originally created in 1979 to extend the celebration of Cook's visit, and in recent years it has begun to incorporate Indigenous performances alongside the re-enactment. ${ }^{49}$ In 2019, the 'Indigenous Showcase' took place the night before the re-enactment. This performance publicly verified the presence of Guugu Yimithirr history on this land, before Cook. The way in which live performances are delivered and received changes through the years. ${ }^{50}$ Particularly in Cooktown, the annual re-enactment and the Indigenous Showcase are community projects, where they are always seeking to refine and add value to the performance. ${ }^{51}$ The performances are not static. The scaffolding of the rescripted encounter has stayed the same since 2009, but the re-enactment is refined with each performance, emphasising the important moments of the past in the present. ${ }^{52}$ Therefore, the following observations are based on these performances in 2019 and their effects in that time.

In this section, I examine the active performances of reconciliation in Cooktown by drawing on Lisa Schirch's understanding of peacebuilding spaces. I define the re-enactment and the Indigenous Showcase as rituals - spaces where symbolic exchanges take place. Schirch argues that 'ritual removes people in conflict from the site of their problematic relationships'. ${ }^{53}$ As a result, I explore how these performances create 'peacebuilding spaces' - spaces where symbolic acts and rituals of conflict resolution can take place. ${ }^{54}$

The re-enactment was as much a memory of the Guugu Yimithirr people as it was of Cook. The stage was on the banks of Waalumbaal Birri, near where Cook had come ashore in 1770 on Guugu Yimithirr Country. The space was significant to both European and Guugu Yimithirr history. Prior to 2009 this space had been used to convey history through a European lens of possession, but today the space had developed new meaning creating a place for a 'shared history' to be performed. ${ }^{55}$ The space had been reclaimed by the Guugu Yimithirr people and the setting became

\footnotetext{
48 Attwood, 'Unsettling Pasts'; Edmonds, “'Walking Together” for Reconciliation'.

49 'Discovery Festival Display by the Cooktown \& District Historical Society', Queensland Museum, accessed 8 October 2019, www.qm.qld.gov.au/microsites/collecting-queensland-festivals/festivals-on-display/discovery-festivaldisplay.html.

50 Gapps, 'Performing the Past', 1-50.

51 Alberta Hornsby, in conversation with Charlotte Ward, Cooktown, 13 June 2019.

52 Nugent, "'An Echo of That Other Cry", 193-95.

53 Schirch, Ritual and Symbol in Peacebuilding, 76.

54 Schirch, Ritual and Symbol in Peacebuilding, Chapter 5; Edmonds, "WWalking Together" for Reconciliation', 119.

55 Tuan, Space and Place.
} 
a place of equal power. ${ }^{56}$ Elder and Eric Deeral's daughter, Erica Deeral, stepped onto the stage with the group of bama ${ }^{57}$ performers. She spoke in Guugu Yimithirr as she introduced us to the bama and to the land. Ironically, compared to original re-enactments, Cook was behind the bushes while the Guugu Yimithirr people were introduced. The performance was used, in a sense, to reverse the narrative that the re-enactment had once favoured by opening with the Guugu Yimithirr side of the story. ${ }^{58}$

The introduction of the Guugu Yimithirr people on stage was followed by a shared performance between Indigenous and non-Indigenous actors. 'Peacebuilding rituals' create an idealised world between cultures in which histories are listened to without day-to-day social restrictions and therefore a form of reconciliation can take place. ${ }^{59}$ The narration of the re-enactment was then shared equally between the Indigenous and non-Indigenous narrators. Loretta Sullivan narrated the crew's thoughts and movements, and Alberta Hornsby narrated the Guugu Yimithirr's. This was now a shared story of the past, where each side would have their turn to share their perspective. The performance provided a space for histories to be shared - they stepped into an idealised world where Indigenous and non-Indigenous sides to history were voiced and listened to. ${ }^{60}$

Schirch contends that 'ritual space develops in part when a unique combination of people join in some unique action' ${ }^{61}$ Cook and the old Guugu Yimithirr man are both actors of reconciliation. They meet in the centre of the stage, which is initiated by the old Guugu Yimithirr man. Hornsby explains that the old man's actions were calling for protection and an atmosphere of peace. Sullivan explains that by giving back the spears Cook 'reconciled everything'. ${ }^{62}$ The re-enactment has become a place of neutrality, like the land that surrounds Waalumbaal Birri, where Indigenous and non-Indigenous characters met in the centre of the stage with equal agency.

The scene brings the audience into the present. The reconciliation scene is the pivotal moment of the re-enactment, followed by Cook and his crew leaving the Endeavour River. Sullivan stated, 'we believe this was the first recorded act of reconciliation in Australia's history'. ${ }^{63}$ Schirch observes that 'ritual can help connect the past with

56 Schirch, Ritual and Symbol in Peacebuilding, 68.

57 Bama means people, more specifically Indigenous people and in this case the Guugu Yimithirr performers.

'Loretta Sullivan and Alberta Hornsby April Luncheon 2015', 38:10-40:15; Ward, 'The Re-Enactment 2019 Part I',

$1: 17-7: 20$.

58 Ward, 'The Re-Enactment 2019 Part I', 1:17-7:20.

59 Schirch, Ritual and Symbol in Peacebuilding, 72-73.

60 Edmonds, “"Walking Together” for Reconciliation', 119.

61 Schirch, Ritual and Symbol in Peacebuilding, 72.

62 'Cook's Journal: Daily Entries, 19 July 1770'; Ward, 'The Re-Enactment 2019 Part V', 1:11-1:14.

63 Ward, 'The Re-Enactment 2019 Part V', 1:15-1:21. 
the present by using a symbolic time to communicate the transformation toward a new future'. ${ }^{64}$ The performance redefines the popular narrative that dominated the re-enactment pre-2009.

Popular histories hold considerable power over the way a nation views its past, and by redefining the narrative from possession to reconciliation the re-enactment becomes an active performance of peacemaking. ${ }^{65}$ The performance gives a snapshot of how Indigenous and non-Indigenous perspectives of the past can be performed and how - by creating a neutral space for this revision to take place - popular histories can be redefined.

This neutral space has also been used to share different histories. The Indigenous Showcase that took place the night before the re-enactment opened with a musical duo, Tamara Gibson and Harold Bowen, who sang songs that had significance to their people. They sang their song 'Evac', which told the story of their people's evacuation from Cape Bedford during the Second World War. The lyrics 'Do you recall the day, when they took our people away from Jepson's to Sandy Bay? By army trucks that came?' were followed by a chorus in Guugu Yimithirr. The audience were not privy to the translation of the chorus, but the sentiments were clear - during World War II the residents were evacuated from Cape Bedford Mission and the reasons why have never been confirmed. ${ }^{66}$ The issues that it caused for the Guugu Yimithirr people have never been resolved. Noel Pearson highlights the lasting impacts to Elders on Cape York Peninsula to this day. ${ }^{67}$ They were displaced, their community was uprooted and many community members never returned.

Inga Clendinnen argues that in order for us to understand how the past has shaped the present we need 'good history, true stories of the making of this present land, none of them simple, some of them painful, all of them part of our individual histories' ${ }^{68}$ Local Bulgun Warra man and the Indigenous Project Officer and Indigenous Guide at the James Cook Museum Harold Ludwick, who I had the pleasure of spending time with in Cooktown, emphasises that we still need to have conversations about dispossession that took place after Cook and about Indigenous views on history. He argues that the performance of reconciliation should not overshadow the history of violence and dispossession that also took place; these stories still need to be told and their ongoing issues resolved. ${ }^{69}$ The performance shared stories from the past, most of them difficult and some of them hopeful. The stage, situated down by Waluumbaal Birri where the re-enactment took place the next day, detached the space from Cook's arrival and

64 Schirch, Ritual and Symbol in Peacebuilding, 70.

65 Healy, 'History, History Everywhere But ...', 183; Edmonds, “Walking Together” for Reconciliation'.

66 See, Richards, "What a Howl There Would Be If Some of Our Folk Were so Treated by an Enemy”'; Pearson,

'Guugu Yimidhirr History', 131-236.

67 Pearson, Up from the Mission, 139-42.

68 Clendinnen, 'True Stories and What We Make of Them', 253.

69 Harold Ludwick, in conversation with Charlotte Ward, 13 June 2019. 
the space was used to voice histories that complicate the understanding of a peaceful process of colonisation. The performance promoted truth-telling by creating a space where more difficult histories could be shared publicly. ${ }^{70}$

The Warrma ${ }^{71}$ was the main event that followed, in which Indigenous dancers performed some of their histories that pre-dated Cook. Tamara Pearson, a Guugu Yimithirr and Guugu Yalanji woman, choreographed the children from the Hope Vale Sacred Creations Dance Troupe as they acted out these histories and shared their dances. Harold Ludwick was the master of ceremonies and coordinated the onstage performances. Ludwick has been responsible for organising the Hope Vale dancers and helping coordinate the Indigenous Showcase for the past two years. ${ }^{72}$

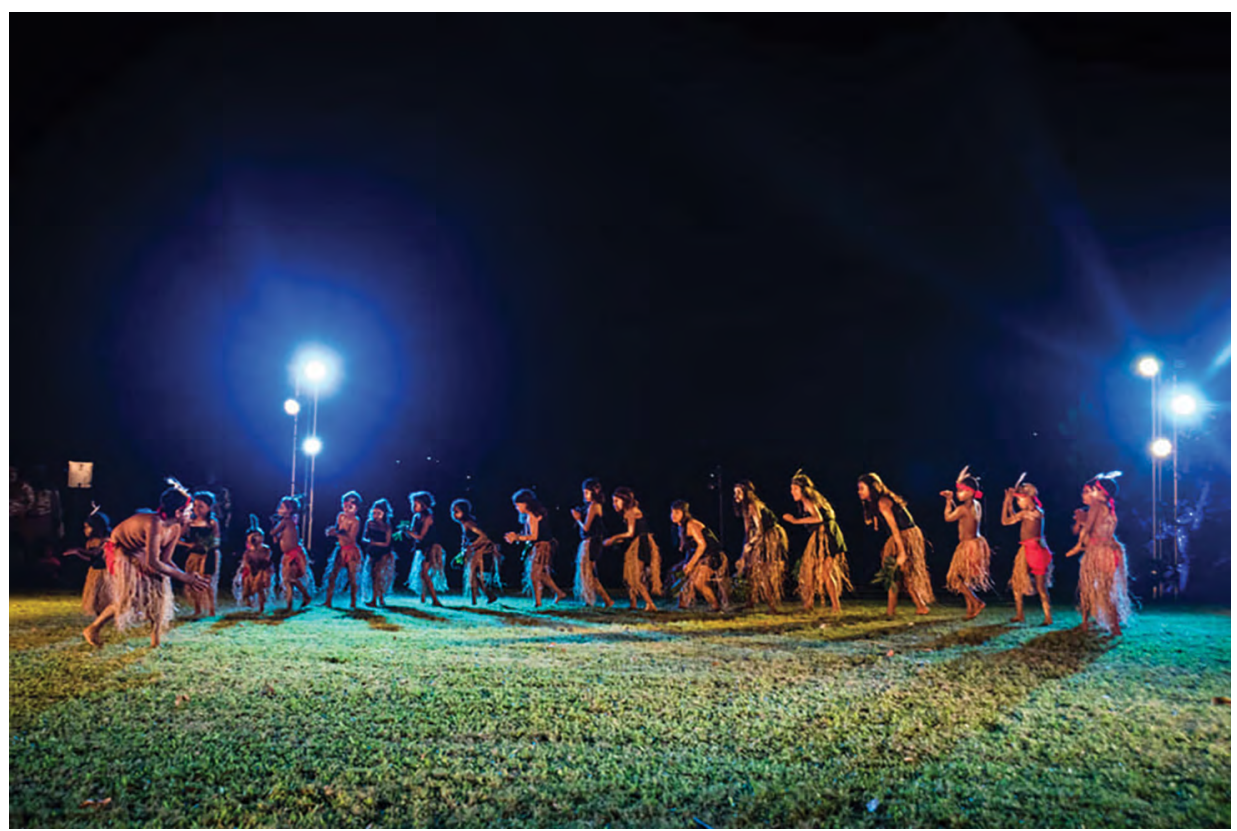

Figure 2: Yirrambal the rainbow serpent, 2019.

Source: With permission from Sacred Creations Dance Troupe.

The Hope Vale dancers were all children, and they were presented to the audience as the vision for their people's future - keeping their history and culture strong. The spaces where rituals take place allow for new ideas and relationships to be performed. They are detached from the prominent concerns of the present and therefore ritual is encouraged and the meanings of different performances are

70 Edmonds, "Walking Together” for Reconciliation'; Schirch, Ritual and Symbol in Peacebuilding.

71 'Warrma' is a Guugu Yimithirr word meaning dance or corroboree. Harold Ludwick, email to Charlotte Ward, 16 September 2019.

72 Harold Ludwick, in conversation with Charlotte Ward, 13 June 2019. 
explored openly. ${ }^{73}$ The histories the Hope Vale dancers shared pre-dated Cook and their performance was scheduled before the re-enactment. It was Guugu Yimithirr history, told by their people, in their form - we learnt about Yirrambal Rainbow Serpent and his creation story, the spirit Dilabulu who took care of naughty children and their totem owl who watches over them. The Discovery Festival has become a space to share and 'discover' different histories, unrelated to Cook's visit.

\section{Conclusion}

Noel Pearson argues that one of the key issues that divides Indigenous and non-Indigenous Australians is 'the troubling business of trying to come to terms with history and the fact that history still lives amongst us and will never depart from us' ${ }^{74}$ Yet, in Cooktown Indigenous and non-Indigenous residents have come together to renegotiate how they remember their shared history. It has required a collaborative approach between Indigenous and non-Indigenous residents that has moved beyond the event in 1770. By revisiting the encounter between Cook's crew and the Guugu Yimithirr people, community members and institutions have begun a process of remembering histories that have previously been overshadowed by the public remembrance of Cook.

The first prominent monument of Cook still stands today in the centre of town. But the town's monumental landscape has expanded to incorporate different perspectives of his visit as well as different histories altogether. As you drive into Cooktown from the inland route, one of the first sites to visit is Reconciliation Rocks. This is the most recent addition to Cooktown's monument collection, but ironically it is one of the oldest. The rocks have always been there, but their significance has not always been recognised. They mark the spot where the reconciliation between Cook and the old Guugu Yimithirr man took place. The place was heritage listed by the National Trust in 2019, the year this was written. Bennett notes that in Cooktown:

most of the major heritage sites in the town today, while preserving these earlier testaments [of colonial possession] to its monumental history, also include Indigenous critiques of celebratory presentations of Cook while simultaneously foregrounding the longer history of the Guugu Yimithirr in rebuttal of narratives of discovery. ${ }^{75}$

The re-enactment in Cooktown acts as a site of negotiation. The performance creates a space where local residents act out their history. Indigenous and non-Indigenous community members volunteer their time, bring ideas to rehearsals and debate the accuracy and importance of their history. As Schirch contends, 'space

73 Schirch, Ritual and Symbol in Peacebuilding, Chapter 5.

74 Council for Aboriginal Reconciliation, The People's Movement for Reconciliation, 32.

75 Bennett, 'Part III: Assembling and Governing Cultures', 273. 
matters'. The annual re-enactment creates a space for 'peacebuilding dramas' to be performed, meaning that the space now promotes a sharing of histories, rather than a restrictive narrative of possession. ${ }^{76}$ Each time the performance is held it is refined, and the moments that resonate most in the present are emphasised and changed. The performance is not so much about how historically accurate the re-enactment is; it is about what the performers choose to remember, how they remember, and what is produced that allows a process of reconciliation of the past to occur. ${ }^{77}$

Furthermore, the space that has been created as a result allows different histories to be performed. The Indigenous Showcase acts as a platform to celebrate history and culture of the Guugu Yimithirr people, but it also helps raise more difficult shared histories and their lasting effects that are yet to be reconciled. Reconciliation between Indigenous and non-Indigenous community members in Cooktown is an ongoing process. One that will continue to take place both on and off the stage. But continuing this process from a shared view of history is a good place to start. ${ }^{78}$

\section{References}

Attwood, Bain. 'Unsettling Pasts: Reconciliation and History in Settler Australia'. Postcolonial Studies 8, no. 3 (August 2005): 243-59. doi.org/10.1080/13688790500231012.

Behrendt, Larissa. 'Speaking Out'. In You plus Me Equals Us: Stories of Reconciliation, Tessa Copland with Leanne Townsend and Julian Boswell. Sydney: New South Wales Reconciliation Council, 2010.

Bennett, Tony. 'Part III: Assembling and Governing Cultures'. In Museums, Power, Knowledge: Selected Essays, 201-90. Milton, UK: Routledge, 2017. doi.org/10.4324/9781315560380.

Chittick, Lee and Terry Fox. Travelling with Percy: A South Coast Journey. Canberra: Aboriginal Studies Press, 1997.

Clendinnen, Inga. Dancing with Strangers. Melbourne, Vic.: Text Publishing, 2003.

Clendinnen, Inga. 'True Stories and What We Make of Them'. In Reconciliation: Essays on Australian Reconciliation, edited by Michelle Grattan, 242-54. Melbourne: Bookman Press, 2000.

Council for Aboriginal Reconciliation. The People's Movement for Reconciliation: Proceedings of the Australian Reconciliation Convention. Canberra, ACT: Council for Aboriginal Reconciliation, 1997.

76 Schirch, Ritual and Symbol in Peacebuilding, 66.

77 Edmonds, “'Walking Together” for Reconciliation'.

78 Newman, 'Reconciliation', 35. 
Dening, Greg. Beach Crossings: Voyaging across Times, Cultures and Self. Melbourne, Vic.: Melbourne University Publishing, 2004.

Dening, Greg. Performances. Melbourne, Vic.: Melbourne University Publishing, 2013.

Edmonds, Penelope. “'Walking Together” for Reconciliation: From the Sydney Harbour Bridge Walk to the Myall Creek Massacre Commemorations'. In Settler Colonialism and (Re)Conciliation: Frontier Violence, Affective Performances, and Imaginative Refoundings, 90-125. London: Palgrave Macmillan, 2016. doi.org/10.1057/9781137304544_4.

French, Robert. 'A Moment of Change - Personal Reflections on the National Native Title Tribunal 1994-98'. Melbourne University Law Review. Accessed 7 October 2019. link. galegroup.com/apps/doc/A111509178/LT?sid=lms.

Gapps, S. G. 'Performing the Past: A Cultural History of Historical Reenactments'. $\mathrm{PhD}$ thesis, University of Technology Sydney, 2002.

Goodall, Heather. 'Too Early yet or Not Soon Enough? Reflections on Sharing Histories as Process'. Australian Historical Studies 33, no. 118 (1 January 2002): 7-24. doi.org/ 10.1080/10314610208596176.

Healy, Chris. From the Ruins of Colonialism: History as Social Memory. Studies in Australian History. Melbourne, Vic.: Cambridge University Press, 1997.

Healy, Chris. 'History, History Everywhere But ...' Australian Historical Studies 23, no. 91 (1 October 1988): 180-92. doi.org/10.1080/10314618808595803.

Healy, Chris. "'We Know Your Mob Now”: European and Aboriginal Histories of Captain Cook', Oral History 19, no. 2 (1991): 27-33.

McCalman, Iain. The Reef: A Passionate History. Brunswick, Vic.: Scribe Publications, 2014.

McKenna, Mark. 'On Grassy Hill: Gangaar (Cooktown), North Queensland'. In From the Edge: Australia's Lost Histories, 163-212. Carlton, Vic.: The Miegunyah Press, 2016.

Molony, John. 'The Guugu Yimithirr'. In Captain James Cook: Claiming the Great South Land, 105-17. Redland Bay, Qld: Connor Court Publishing Pty Ltd, 2016.

National Museum of Australia. 'Sequence_06_Alberta_Hornsby_Overlay'. October 2018.

Newman, Paul. 'Reconciliation'. In Knowledge of Life: Aboriginal and Torres Strait Islander Australia, edited by Kaye Price, 26-37. Port Melbourne: Cambridge University Press, 2015. doi.org/10.1017/CBO9781316151112.002.

Nietzsche. The Use and Abuse of History, Mineola, New York: Dover Publications, 2019.

Nugent, Maria. “'An Echo of That Other Cry” Re-Enacting Captain Cook's First Landing as Conciliation Event'. In Conciliation on Colonial Frontiers: Conflict, Performance, and Commemoration in Australia and the Pacific Rim, edited by Kate Darian-Smith and Penelope Edmonds, 193-209. Melbourne, Vic.: Routledge, 2015. doi.org/10.4324/ 9781315812946-11. 
Nugent, Maria. Captain Cook Was Here. Melbourne, Vic.: Cambridge University Press, 2009.

Pearson, Noel. 'Guugu Yimidhirr History: Hope Vale Lutheran'. In Maps, Dreams, History: Race and Representation in Australia, edited by Jan Kociumbas, 131-236. Sydney: Department of History, University of Sydney, 1998.

Pearson, Noel. Up from the Mission: Selected Writings. 2nd ed. Collingwood, Vic.: Black Inc., 2011.

Richards, Jonathan. "What a Howl There Would Be If Some of Our Folk Were so Treated by an Enemy": The Evacuation of Aboriginal People from Cape Bedford Mission, 1942'. Aboriginal History 36 (January 2013): 67-98. doi.org/10.22459/AH.36.2013.04.

Rose, Deborah Bird. Hidden Histories: Black Stories from Victoria River Downs, Humbert River and Wave Hill Stations. Canberra: Aboriginal Studies Press, 1991.

Schirch, Lisa. Ritual and Symbol in Peacebuilding. Bloomfield: Kumarian Press, 2005.

Thomas, Nicholas. Cook: The Extraordinary Voyages of Captain James Cook. London, UK: Walker, 2004.

Thomas, Nicholas. Discoveries: The Voyages of Captain Cook. London: Penguin UK, 2018.

Thomas, Nicholas. Entangled Objects: Exchange, Material Culture, and Colonialism in the Pacific. Cambridge, MA: Harvard University Press, 2009. doi.org/10.2307/j.ctvmd86bt.

Tuan, Yi-fu. Space and Place: The Perspective of Experience. Minneapolis: University of Minnesota Press, 1977.

Ward, Charlotte. 'The Re-Enactment 2019 Part I'. Video Recording. 16 June 2019.

Ward, Charlotte. 'The Re-Enactment 2019 Part V’. Video Recording. 16 June 2019. 
This text is taken from Aboriginal History, Volume 44, 2020, edited by Crystal McKinnon and Ben Silverstein, published 2021 by ANU Press, The Australian National University, Canberra, Australia.

doi.org/10.22459/AH.44.2020.01 